\title{
Justification of Entrepreneur: As a Fourth Factor of Production
}

\author{
Dr.Farooq Aziz, Syed Muhammad Fahim, Waqar Ud Din Usmani, \\ Muhammad Rizwan \\ Department of Business Administration Assistant Professor Federal Urdu University Karachi-Pakistan \\ Department of Management Sciences Assistant Professor DHA Suffa University Karachi-Pakistan \\ Department of Business Administration Assistant ProfessorInstitute of Business echnology Karachi-Pakistan \\ Department of Business Administration Lecturer Dow University of Health Sciences Karachi-Pakistan
}

\begin{abstract}
Entrepreneur as a fourth factor of production was introduced in the beginning of $18^{\text {th }}$ century. Entrepreneur defined as a person who organized and managed the business and takes the risk to get profit. It is assumed that since none of the other factors of production perform these functions hence entrepreneur has a separate identity. But actually it is a fallacy, almost all the persons in this world perform same functions many times in their life but they are not entitled for profit or get any special identity. Actual fact is that, these functions are compulsory part of the nature of entrepreneur's work like other human being. Hence entrepreneur should be considered as part of labour and cannot be justify as a spate identity.
\end{abstract}

JEL Classification: D81; G23:33; L11; M10; M11

Key Words: Entrepreneur: Factors of production; Organization, Management; Risk.

\section{Introduction}

As compare to other factors of production entrepreneur is a new member of this club as introduced in the beginning of $18^{\text {th }}$ Century Organization, management co-ordination and taking of risk are basic functions which are associated with entrepreneur and due to these functions entrepreneur gets a separate identity in the modern business and economics. But the main question is, are these functions just associated with entrepreneur? In the other words except entrepreneur any other human being did not perform these functions? The real but the bitter fact is that, these functions are not just restricted to entrepreneur. These are quite common functions which almost all the human beings are performed in their daily life. Hence entrepreneur do not has any specialty in this regard. In order to clarify this concept in the following sections of this paper first a brief historical development of this concept is highlighted and then with the help of a critical analysis it is proved that entrepreneur as a separate factor of production does not exist.

\section{A Brief Historical Development of Entrepreneurship Concept}

Entrepreneur as a term was introduced by an Irish-French economist Richard Contillon In his opinion entrepreneur is a person who purchase raw material to manufacture some new products, takes the risk. (Schumpeter 1951). This term was first time appeared in French dictionary "Dictionnarie Universal de Commerce" of Jacqes des Bruslons, published in 1723.

This concept in its dormant form was present in the Middle Age. At that time, that person was considered as entrepreneur who achieves any objective e.g. construction of a building or completion of any project etc. In its initial form it was introduced in different classical economists e.g. Alfred Marshall, J.B. Say, J.S. Mill and David Ricardo etc. Marshall has recognized the need of entrepreneurship in 1890 and admitted it as the fourth factor of production along with land, labour and capital. In his opinion this is a coordinated factor which combines the other factors of production and he has considered it as the driver of organization. For this purpose in his opinion entrepreneur should be a natural leader, he has the capability to forecast the changes in demand and supply, this capability puts the entrepreneur in the list of extraordinary personalities (Marshall 1994).

In the opinion of French economist J.B. Say entrepreneur is also a leader, he has also introduced the concept of co-ordination in the functions of entrepreneur. David Ricardo and J.S. Mill has tried to present this concept under a broader English term "Business Management", and also admit that, in English language there is not any word which can be used as synonymous of this term. In $20^{\text {th }}$ century when the extraordinary expansion took place in business due to a lot of new products \& innovations the concept of entrepreneur has got a significant importance. Joseph Schumpetor has given the whole credit of this expansion to entrepreneur. In $20^{\text {th }}$ Century this concept has got his modern form which is a single person who is responsible for the whole organization or corporation.

According to a modern school of thought entrepreneur is an innovator, however there is not any consensus on the definition of innovator. (Kizner 1985). Many economists considered entrepreneur as an 
innovator, but this theory is not applicable on developing countries. In these countries entrepreneur is not innovator in its traditional meaning. In these countries rarely new products are introduced, instead of that entrepreneur of these countries just copy of the ideas of rest of the world or follow the way of traditional production. The term "creative limitation" which is used in developed countries is not applicable in these countries in its true sense (Drucker 1985). In these countries innovation process is the alternate name of adaption of old methods and products etc.

It is also important to note that the level of empirical research on entrepreneur is very low as compare to the other factors of production, which adversely effected the development of economics as a subject. Its main reason is that empirical measurement of entrepreneurship is not possible due to imperfect competition, failure of market and uncertain production function. Due to these factors entrepreneur cannot be entered in an economic model (Leibenstein 1995).

On the basis of above discussion it can be said that, from its beginning entrepreneur becomes an abstract concept and different thinkers has associated different characteristics with it. Some has suggested that entrepreneur is a person who bears uncertainty, (Swaboda, 1983), other's considered him as a coordinator of resources (Amold 1996) and in the opinion of some others entrepreneur is an innovator and a person who provides capital (Hoseliz 1952). So, it can be said that there is not any hard \& fast definition of this concept which is acceptable for all economists and which is applicable to all economies. However, there is a consensus on the basic functions of entrepreneurs. On this ground in modern economics entrepreneur may be defined in these words "a person who organizes and manages any enterprise especially a business usually with considerable initiative and risk". (www.dictionary.reference. com/browse/entrepreneur).

\section{A Critical Analysis of Entrepreneur's Function.}

From economic point of view an impression is given that entrepreneur performs some unique functions and on the basis of that he/she deserves for profit. From the above discussion it can be conclude that these functions are organization management and taking of risk. Now the question is are there functions just associated with entrepreneur. The real but the quite bitter fact is that these functions cannot be restricted just to entrepreneurs these are quite common functions of everymen's life. All human beings perform these functions many times in their ordinary life. Hence there is not any difference between entrepreneurs and other human being in this regard all of them are quite same. A brief analysis of functions of entrepreneurs is as follows.

\subsection{Organization}

It is claimed that entrepreneurs organize the business which is the fundamental function because without organization no work can be done. The term organization may be defined in different ways e.g. it is the act or process or organizing or the act of rearranging the things under one or more than one rules. In ordinary life anything is considered as organized when it should be in a correct order and right place. On this basis it may also be defined as logical arrangement of different things for better searching. Specialization and division of work these are two basic pillars of entire philosophy of organization. The division of work means the assigning of responsibilities to each organizational component or specific individual or group thereof. It takes the form of specialization when the personality for a specific task lies with a designated expert in that field.

At here a simple question may be asked that, is there any work in the ordinary life of all human being which can be done without organization? The answer of this question is no. Each and every job or objective must require organization. Without organization it is almost impossible to complete any work or achieve any objective in our daily life. Hence each and every human being is compel to organize his / her work, it does not matter what is the nature of work and what is the level and quality of organization. Hence organization is the compulsory part of all human being in all of their work and entrepreneurs do not have any distinction in this regard. Entrepreneurs just organize his / her business like the other professionals and ordinary persons hence nothing is special with entrepreneurs in this regard.

\subsection{Management}

The term management means the act of coordinating the efforts to accomplish desired goals and objectives using available resources effectively and efficiently. There are five basic functions of management, these are planning, organizing staffing, leading / directing and controlling. Moreover motivation and coordination are also important in this regard. The entrepreneur performs all these functions to run his business. The situation is again same in this context; these functions of management are not just restricted to entrepreneur. All human beings have to plan and organize their work (regardless of nature of work). They cannot do any work or achieve any objective without motivation and they also have to control and lead themselves to accomplish their goals and may recruit the persons if necessary. The level and quality of these functions are depending on the nature of work or objective, some as the case of entrepreneur. Hence again it is a common practice of all human being there is not any point of distinction is left for entrepreneur. 


\subsection{Element of Risk}

Almost majority of the economic thinkers feel that since the entrepreneur takes the risk, hence it is a special mark of distinction and it gives entrepreneur a special identity because rest of the factors don't take any risk. Once again it is not any sign of pride or base of separate identity, because there are some other professions in which the degree of risk is much higher than the entrepreneur. The most significant example is gambler, who takes the highest degree of risk. If the risk is the base, then all gamblers should be treated as the best entrepreneur because the level of risk in gambling is much higher than any other business, but any gambler cannot be treated as entrepreneur. Same as there are some other professions in which the degree of risk is also very high but they are not treated as entrepreneur e.g. pilots, marine engineers, and mine workers etc.

Actually each profession has some unique characteristics e.g. direct communication is the main characteristic of teaching and journalism, face impression in acting, pleasant conversation is sales etc., but these characteristics cannot give any special status to these professionals. The same situation is with business, in which more or less degree of risk is involved which a businessman has to face, but this normal characteristic of business cannot be a base of a separate identity. It is a part of their profession and should be taken it as part only not more than that. Moreover the element of risk is associated with each and every person on the earth in different ways, different examples can be given in this regard e.g. the jobs of all workers are always at risk, a driver when drives any vehicle he/she takes the risk of accident, a student when gives the examination he/she is also at risk, will he / she pass or not, a passenger of any train / ship / plane also takes the risk of accident. Will all of them treat as entrepreneurs?

It can be concluded that risk is a quite common element of life for any one and anywhere and cannot be taken as the basic characteristic of entrepreneur. The real fact is that entrepreneur by himself do not have any separate identity, it is a fallacy not more than that. Entrepreneurship is just a form of labour and it should be treated as that. Hence entrepreneur as a factor of production does not exist and should be treated as labour only.

\section{Conclusion:}

Entrepreneur is considered as fourth factor of production on the basis of some functions like organization, management and taking of risk. But all of these functions are performed by almost all the human being and these functions are the part of daily life of all men and women on the earth. All human being organized and manage their different works / jobs/ projects etc., without organization and management how any work can be completed? Hence it is a common practice of all men and women. Some as all human being in their daily life takes different types of risk and it is another common characteristic of human life. Hence entrepreneur doesn't perform any unique function and on this basis cannot claim any separate identity. The real fact is that all the activities of entrepreneur just fall in the category of labour, hence it is a form of labour not more than that.

[1]. Amold, Roger, 1996 Economics, 18

\section{References}

[2]. Drucker, Peter F. 1985 Innovation and Entrepreneurship: Practices \& Principles, 220- 225

[3]. Hoselitz, B.F., 1952 Entrepreneurship \& Economic Growth, 12

[4]. Kizner, Israel M., 1985 Discovery and the Capitalist process 10-70

[5]. Leibenstein, Harvey, The Supply of Entrepreneurship leading issues in Economic Development 273-275

[6]. Marshall, Alfred 1994 Principles of Economics 248-258

[7]. Schumpeter, Joseph A., 1951 Essays of J.A. Schumpeter 248-250

[8]. Swaboda, Peter, 1983 Schumpeter's Entrepreneurs in Modern Economics Theory, Lectures on Schumpeterian Economics 17-25

[9]. Websites: www.dictionary.reference.com/browse/ entrepreneure. 